\title{
Rhodothermus obamensis sp. nov., a Modern Lineage of Extremely Thermophilic Marine Bacteria
}

\author{
YOSHIHIKO SAKO, ${ }^{1 *}$ KEN TAKAI, ${ }^{1}$ YUZABURO ISHIDA, ${ }^{1}$ ARITSUNE UCHIDA, ${ }^{1}$ \\ AND YOKO KATAYAMA ${ }^{2}$
}

\author{
Laboratory of Marine Microbiology, Department of Applied Bioscience, Graduate School of Agriculture, Kyoto \\ University, Kyoto 606-01, ${ }^{1}$ and Department of Environmental and Natural Resources Science, Faculty of Agriculture, \\ Tokyo University of Agriculture and Technology, Fuchu, Tokyo 183, ${ }^{2}$ Japan
}

\begin{abstract}
A novel extremely thermophilic bacterium was isolated from a shallow marine hydrothermal vent environment (depth, $22 \mathrm{~m}$ ) in Tachibana Bay, Nagasaki Prefecture, Japan. The cells of this organism were gramnegative rods. Growth occurred at temperatures between 50 and $85^{\circ} \mathrm{C}$ (optimum temperature, $80^{\circ} \mathrm{C}$; doubling time at optimum temperature, $90 \mathrm{~min}$ ), at pH 5.5 and 9.0 (optimum pH, 7.0), and in the presence of 1 and $5 \%$ $\mathrm{NaCl}$ (optimum $\mathrm{NaCl}$ concentration, 3\%). The new isolate was an aerobic heterotroph which utilized the following compounds as sole energy and carbon sources: yeast extract, peptone, starch, casein, Casamino Acids, a variety of sugars, some carboxylic acids, and amino acids. As determined by a sequence analysis of the $16 \mathrm{~S}$ rRNA, the new isolate belongs to the genus Rhodothermus and represents a modern lineage of extreme thermophiles within the domain Bacteria. On the basis of the physiological and molecular properties of the new isolate, we describe a new species, Rhodothermus obamensis. The type strain of $R$. obamensis is strain OKD7 (= JCM 9785).
\end{abstract}

Over the last 10 years, a number of new genera and species of thermophilic organisms which are capable of growth at temperatures up to $80^{\circ} \mathrm{C}$ have been isolated. Most of these organisms belong to the domain Archaea (31), but there are a few genera, such as the genera Thermus, Thermotoga, and Aquifex, which belong to the domain Bacteria $(5,10,11)$. These thermophiles have distinct physiological differences; the members of the genus Thermus are strictly aerobic heterotrophs, the members of the genus Thermotoga are strictly anaerobic heterotrophs, and the members of the genus Aquifex are microaerobic chemolithoautotrophs. On the basis of $16 \mathrm{~S}$ rRNA analysis data, the genera Thermotoga and Aquifex represent the deepest phylogenetic branches in the domain Bacteria $(7,21)$. Moreover, the genus Thermus also branches deeply on the phylogenetic tree inferred from 16S rRNA sequences (21). These findings and the results of a phylogenetic study of the thermophilic genus Hydrogenobacter support the hypothesis that the ancestors of bacteria were thermophilic species $(1,26)$.

The members of the genus Rhodothermus, on the other hand, are marine thermophilic bacteria that have been isolated from sites in Iceland and the Azores $(2,20)$. Rhodothermus marinus is an aerobic heterotrophic bacterium that has an optimum growth temperature of $65^{\circ} \mathrm{C}$ and has been used in studies of genetic engineering of thermostable enzymes (28). A $16 \mathrm{~S}$ rRNA analysis of this organism placed the genus Rhodothermus close to the root of the Flexibacter-Cytophaga-Bacteroides group with affinities to the green sulfur bacteria, fibrobacteria, and spirochetes (3). This phylogenetic position of the genus Rhodothermus differs from the phylogenetic positions of other thermophilic bacteria and suggests that there are thermophilic or extremely thermophilic bacteria which are distant from the universal root of life and that there was another origin of thermophily within the Bacteria (3).

In this paper, we describe the isolation and characterization of a new extremely thermophilic Rhodothermus species that

* Corresponding author. Phone: 81-75-753-6218. Fax: 81-75-7536226. Electronic mail address: mmb@kais.kyoto-u.ac.jp. was obtained from a shallow marine hydrothermal vent and discuss the importance of the phylogenetic position of this organism to the hypothesis that the origin of thermophily within the Bacteria is ancient.

\section{MATERIALS AND METHODS}

Collection of samples. Effluent water samples from hydrothermal vents and sedimentary materials adjacent to vents were collected from Tachibana Bay, Nagasaki Prefecture, Japan, at a depth of $22 \mathrm{~m}$. The temperatures of the hydrothermal vent fluids were 120 to $125^{\circ} \mathrm{C}$. Samples were stored aerobically at room temperature for $6 \mathrm{~h}$ prior to incubation.

Enrichment and purification. Subsamples of effluent water and sediment samples were used to inoculate a series of media, including $\mathbf{J x}$ medium (see below). All of the Jx medium tubes containing sediment were turbid after 1 day of incubation at $80^{\circ} \mathrm{C}$. To obtain a pure culture, enriched cells were streaked onto $\mathrm{Jx}$ medium plates and the plates were incubated at $70^{\circ} \mathrm{C}$. Well-defined colonies were picked and streaked onto another plate, and this plate was incubated at $70^{\circ} \mathrm{C}$. This procedure was repeated at least five times. A pure colony that was red was designated strain $\mathrm{OKD} 7^{\mathrm{T}}(\mathrm{T}=$ type strain $)$.

Culture medium and conditions. The new isolate was routinely cultivated in $\mathbf{J x}$ medium, which contained (per liter) $35 \mathrm{~g}$ of Jamarin S synthetic seawater powder (Jamarin Laboratory, Osaka, Japan), $5 \mathrm{ml}$ of Jamarin S synthetic seawater solution (Jamarin), $1 \mathrm{~g}$ of yeast extract (Difco Laboratories, Detroit, Mich.), and $1 \mathrm{~g}$ of Trypticase peptone (BBL, Cockeysville, Md.); the $\mathrm{pH}$ of this medium was adjusted to 6.8 to 7.2 with $\mathrm{H}_{2} \mathrm{SO}_{4}$. For growth on plates, $3 \%$ (wt/vol) GP-700 agar (Shimizu Shokuhin, Shimizu, Japan) was added to Jx medium. To determine the effect of $\mathrm{NaCl}$ on growth, different concentrations of an $\mathrm{NaCl}$ solution (pH 7.0) containing $0.1 \%$ (wt $/ \mathrm{vol}$ ) yeast extract and $0.1 \%$ (wt/vol) peptone were used instead of $\mathrm{Jx}$ medium. In order to determine the effects of temperature and $\mathrm{pH}$ on growth, the new isolate was cultivated in $\mathrm{MJ}$ medium, which contained (per liter) $30.0 \mathrm{~g}$ of $\mathrm{NaCl} ; 0.14 \mathrm{~g}$ of $\mathrm{K}_{2} \mathrm{HPO}_{4} ; 0.14 \mathrm{~g}$ of $\mathrm{CaCl}_{2} \cdot 2 \mathrm{H}_{2} \mathrm{O} ; 0.25 \mathrm{~g}$ of $\mathrm{NH}_{4} \mathrm{Cl}$; $3.4 \mathrm{~g}$ of $\mathrm{MgSO}_{4} \cdot 7 \mathrm{H}_{2} \mathrm{O} ; 4.18 \mathrm{~g}$ of $\mathrm{MgCl}_{2} \cdot 6 \mathrm{H}_{2} \mathrm{O} ; 0.33 \mathrm{~g}$ of $\mathrm{KCl} ; 0.5 \mathrm{mg}$ of $\mathrm{NiCl}_{2} \cdot 6 \mathrm{H}_{2} \mathrm{O} ; 0.5 \mathrm{mg}$ of $\mathrm{Na}_{2} \mathrm{SeO}_{3} \cdot 5 \mathrm{H}_{2} \mathrm{O} ; 0.01 \mathrm{~g}$ of $\mathrm{Fe}\left(\mathrm{NH}_{4}\right)_{2}\left(\mathrm{SO}_{4}\right)_{2} \cdot 6 \mathrm{H}_{2} \mathrm{O} ; 10$ $\mathrm{ml}$ of a trace mineral solution containing (per liter) $1.5 \mathrm{~g}$ of nitrilotriacetic acid, $3.0 \mathrm{~g}$ of $\mathrm{MgSO}_{4} \cdot 7 \mathrm{H}_{2} \mathrm{O}, 0.5 \mathrm{~g}$ of $\mathrm{MnSO}_{4} \cdot 2 \mathrm{H}_{2} \mathrm{O}, 1.0 \mathrm{~g}$ of $\mathrm{NaCl}, 0.1 \mathrm{~g}$ of $\mathrm{FeSO}_{4} \cdot 7 \mathrm{H}_{2} \mathrm{O}, 0.18 \mathrm{~g}$ of $\mathrm{CoSO}_{4} \cdot 7 \mathrm{H}_{2} \mathrm{O}, 0.1 \mathrm{~g}$ of $\mathrm{CaCl}_{2} \cdot 2 \mathrm{H}_{2} \mathrm{O}, 0.18 \mathrm{~g}$ of $\mathrm{ZnSO}_{4} \cdot 7 \mathrm{H}_{2} \mathrm{O}, 0.01 \mathrm{~g}$ of $\mathrm{CuSO}_{4} \cdot 5 \mathrm{H}_{2} \mathrm{O}, 0.02 \mathrm{~g}$ of $\mathrm{KAl}\left(\mathrm{SO}_{4}\right)_{2} \cdot 12 \mathrm{H}_{2} \mathrm{O}, 0.01 \mathrm{~g}$ of $\mathrm{H}_{3} \mathrm{BO}_{3}, 0.01 \mathrm{~g}$ of $\mathrm{Na}_{2} \mathrm{MoO}_{4} \cdot 2 \mathrm{H}_{2} \mathrm{O}, 0.025 \mathrm{~g}$ of $\mathrm{NiCl}_{2} \cdot 6 \mathrm{H}_{2} \mathrm{O}$, and $0.3 \mathrm{mg}$ of $\mathrm{Na}_{2} \mathrm{SeO}_{3} \cdot 5 \mathrm{H}_{2} \mathrm{O} ; 1 \mathrm{~g}$ of yeast extract; and $1 \mathrm{~g}$ of Trypticase peptone. The $\mathrm{pH}$ of $\mathrm{MJ}$ medium was adjusted to 6.8 to 7.2 with $\mathrm{H}_{2} \mathrm{SO}_{4}$ for the growth temperature test and to various values with $\mathrm{H}_{2} \mathrm{SO}_{4}$ or $\mathrm{NaOH}$ for the pH test. To examine the utilization of carbon-containing substrates, the yeast extract and peptone in $\mathrm{MJ}$ medium were replaced with various concentrations of substrates.

Light microscopy. Cells were routinely observed with a differential interference microscope (Nikon). For microscopy at $80^{\circ} \mathrm{C}, 1$ drop of a hot culture was placed on a slide that had been preheated to about $85^{\circ} \mathrm{C}$ and was observed 
immediately. Micrographs were taken with a Nikon optishot microscope equipped with a Nikon FX-II camera system.

Determination of growth. Growth of the new isolate was determined by measuring turbidity at $660 \mathrm{~nm}$ and by direct cell counting after preparations were stained with 4',6-diamidino-2-phenylindole. Duplicate cultures were grown in 300 -ml flasks containing $100 \mathrm{ml}$ of medium in a temperature-controlled dry oven (Advantec, Tokyo, Japan) and were shaken at $100 \mathrm{rpm}$. The growth curves under changing $\mathrm{pH}$ and $\mathrm{NaCl}$ concentration conditions were determined at $75^{\circ} \mathrm{C}$.

Organic substrates for growth. To find organic substrates which supported growth of the new isolate, experiments were conducted in $\mathrm{MJ}$ medium containing potential substrates in place of yeast extract and peptone. The potential substrates were added at concentrations of $0.01,0.05$, and $0.1 \%$ (wt/vol). Cells were precultured in each medium and inoculated into the same medium. Duplicate tests were performed at $75^{\circ} \mathrm{C}$.

Cellular fatty acid and quinone compositions. Cellular fatty acid and quinone compositions were determined by using $\mathrm{OKD}^{\mathrm{T}}$ cells cultivated in $\mathrm{Jx}$ medium at $75^{\circ} \mathrm{C}$. The cellular fatty acid content was determined as described by Kawasumi et al. (14), while the major quinone content was determined as described by Ishii et al. (12).

Isolation and base composition of DNA. DNA was prepared as described by Marmur and Doty (19) and Lauerer et al. (18). The G+C content of the DNA was determined by directly analyzing the deoxyribonucleotides by high-performance liquid chromatography (27). A DNA GC kit (Yamasa, Chiba, Japan) was used as the standard.

Amplification of 16S rRNA gene and sequence determination. The 16S rRNA gene was amplified by the PCR. The sequences of the primers used for amplification were 5'-AGAGTTTGATCCTGGCTCAG-3' and 5'-GGTTACCTTCC TCCGGCTTA-3', corresponding to positions 8 to 27 and 1492 to 1511 , respectively, in the $16 \mathrm{~S}$ rRNA sequence of Escherichia coli (6). The 1.5-kb PCR product was directly sequenced by the dideoxynucleotide chain termination method by using a model 373As DNA sequencer (Applied Biosystems, Inc.). The DNA sequence data were used in a sequence homology search with previously described $16 \mathrm{~S}$ rRNA sequences by using DNASIS software (Hitachi Software, Tokyo, Japan).

Data analysis. The almost complete $16 \mathrm{~S}$ rRNA sequence of $O K D 7^{\mathrm{T}}$ was aligned with other sequences, and the evolutionary distances ( $K_{\text {nuc }}$ values) were calculated by using 1,407 nucleotides (corresponding to position 29 to position 1436 on the $E$. coli $16 \mathrm{~S}$ rRNA sequence). The ODEN version 1.1.1 software package (National Institute of Genetics, Mishima, Japan) was used to align multiple sequences, to calculate the $K_{\text {nuc }}$ values, and to construct a phylogenetic tree based on the results of the neighbor-joining method (24) and a bootstrap examination.

Nucleotide sequence accession number. The almost complete 16S rRNA sequence of strain $O K D 7^{\mathrm{T}}$ has been deposited in the EMBL nucleotide sequence database under accession number X95071.

\section{RESULTS}

Enrichment and purification. Enrichment took place from sedimentary materials in $\mathrm{Jx}$ medium at $80^{\circ} \mathrm{C}$, and a mixed population of coccoid and long, thin, rod-shaped cells were observed after 1 day of incubation. A culture containing rodshaped cells was purified during repeated plating at $70^{\circ} \mathrm{C}$. A single red colony was used as the inoculum for a liquid culture that was designated strain $\mathrm{OKD} 7^{\mathrm{T}}\left(=\mathrm{JCM} 9785^{\mathrm{T}}[\mathrm{J}\right.$ apan Collection of Microorganisms, Wako, Japan]). All experiments were performed with isolate $\mathrm{OKD} 7^{\mathrm{T}}$.

Morphology. Cells of $\mathrm{OKD} 7^{\mathrm{T}}$ were gram-negative rods which were 4 to $10 \mu \mathrm{m}$ long and 0.5 to $1.0 \mu \mathrm{m}$ wide in the exponential growth phase (Fig. 1A). In the stationary phase, the cells tended to occur in aggregates (Fig. 1B) and to become extremely long (Fig. 1C). Isolate OKD7 grew vigorously with shaking and was a typical aerobe.

Temperature range for growth and effects of $\mathrm{pH}$ and salt concentration. The new isolate grew at temperatures of about 50 to $85^{\circ} \mathrm{C}$; the optimum temperature was $80^{\circ} \mathrm{C}$, and the generation time at $80^{\circ} \mathrm{C}$ was about $1.5 \mathrm{~h}$ (Fig. 2A). No growth occurred at $90^{\circ} \mathrm{C}$. Growth of the new isolate occurred at $\mathrm{pH}$ values between $\mathrm{pH} 5.5$ and 9.0, and the optimum $\mathrm{pH}$ was about 7.0 (Fig. 2B). No significant change in $\mathrm{pH}$ was observed during growth, and no growth was detected at $\mathrm{pH}$ values below 5.5 or above 9.0 .

Strain $\mathrm{OKD}^{\mathrm{T}}$ required $\mathrm{NaCl}$ for growth. It grew in the presence of about 1 to $5 \% \mathrm{NaCl}$, and the optimum $\mathrm{NaCl}$
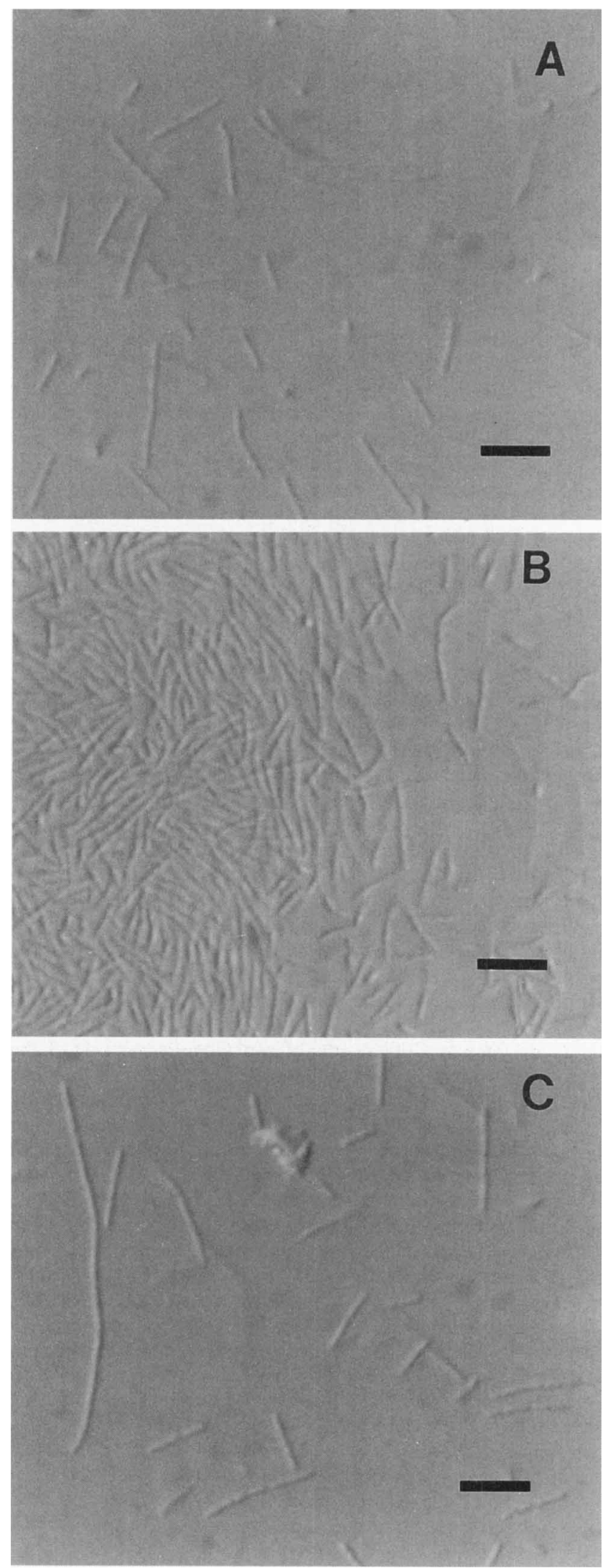

FIG. 1. Differential interference micrographs of $R$ obamensis cells. (A) Exponentially growing cells. (B) Aggregated cells in the stationary phase. (C) Filamentous cells in the stationary phase. Bars $=5 \mu \mathrm{m}$. 

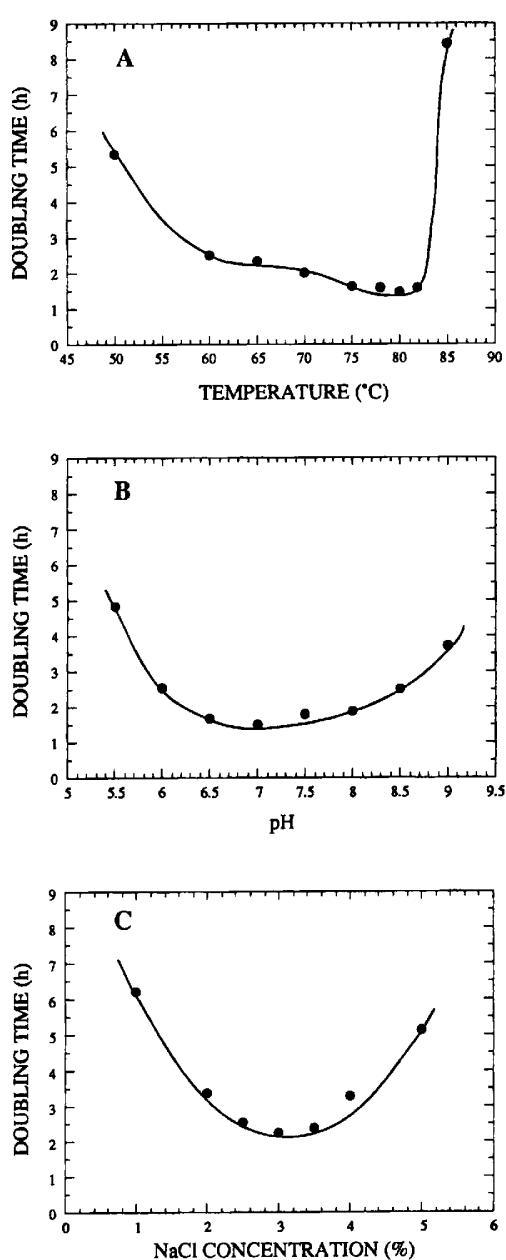

FIG. 2. Effects of temperature, $\mathrm{pH}$, and $\mathrm{NaCl}$ on the growth of $R$. obamensis. (A) Temperature range for growth of $R$. obamensis in MJ medium having an initial $\mathrm{pH}$ of 6.8 to 7.2 . No growth occurred at temperatures below $50^{\circ} \mathrm{C}$ and above $85^{\circ} \mathrm{C}$. (B) $\mathrm{pH}$ range for growth of $R$. obamensis in $\mathrm{MJ}$ medium at $75^{\circ} \mathrm{C}$. The initial $\mathrm{pH}$ was adjusted with $\mathrm{H}_{2} \mathrm{SO}_{4}$ or $\mathrm{NaOH}$ at room temperature. (C) Effect of $\mathrm{NaCl}$ on growth of $R$. obamensis at $75^{\circ} \mathrm{C}$. For this experiment, solutions containing different concentrations of $\mathrm{NaCl}, 0.1 \%$ (wt/vol) yeast extract, and peptone ( $\mathrm{pH} 7.0$ ) were used.

concentration was around $3 \% \mathrm{NaCl}$ (Fig. 2C). At $\mathrm{NaCl}$ concentrations below $1 \%$ or above $5 \%$, the cells lysed within $2 \mathrm{~h}$.

Nutrition. Strain OKD $7^{\mathrm{T}}$ was a heterotroph. In MJ medium containing $0.1 \%$ (wt/vol) yeast extract and $0.1 \%$ (wt/vol) peptone, OKD $7^{\mathrm{T}}$ grew vigorously with a generation time of about $1.5 \mathrm{~h}$ and reached a maximum cell density of more than $10^{9}$ cells per ml. Similar growth rates and somewhat lower maximum cell densities were observed when $0.1 \%$ (wt/vol) yeast extract, peptone, and Casamino Acids were used as sole energy and carbon sources, whereas with sucrose, mannitol, sorbitol, or starch the growth rates and cell yields were quite similar to the growth rates and cell yields with $0.1 \%$ (wt/vol) yeast extract and peptone (Table 1). The new isolate also utilized a variety of sugars, amino acids, and other compounds as substrates for growth (Table 1). Very weak growth occurred in the presence of valine, and no growth occurred in the presence of xylose, glycerol, glutamine, or leucine (Table 1). In addition, high concentrations of carbohydrates inhibited growth, as shown for glucose (Table 1 and data not shown). In contrast, the growth rates and cell yields increased with the concentrations of sub- strates such as carboxylic acids, amino acids, Casamino Acids, and casein (Table 1 and data not shown).

Fatty acid and quinone compositions. When the new isolate was grown at $75^{\circ} \mathrm{C}$, the major cellular fatty acids were iso- $\mathrm{C}_{17}$ acid $(39 \%)$, anteiso- $\mathrm{C}_{15}$ acid $(19 \%)$, anteiso- $\mathrm{C}_{17}$ acid $(16 \%)$, and iso- $\mathrm{C}_{15}$ acid $(15 \%)$. This fatty acid composition was similar to the fatty acid composition of Thermus spp. (Table 2). However, there was a significant difference between the quinone composition of $\mathrm{OKD} 7^{\mathrm{T}}$ and the quinone composition of Thermus spp. Menaquinone 8 is the major menaquinone of Thermus spp., but menaquinone 7 is the major respiratory quinone $(83 \%)$, and menaquinones 5 and 6 are also present ( 7 and $10 \%$, respectively); however, no menaquinone 8 was detected in $\mathrm{OKD}^{\mathrm{T}}$ (Table 2).

DNA base composition. The $\mathrm{G}+\mathrm{C}$ content of $\mathrm{OKD} 7^{\mathrm{T}}$ was $66.6 \mathrm{~mol} \%$, a value similar to the values obtained for $R$. $\mathrm{ma}$ rinus and Thermus spp. (Table 2).

Phylogenetic analyses. The almost complete $16 \mathrm{~S}$ rRNA sequence of $O K D 7^{\mathrm{T}}$ was determined and was found to be $95 \%$ similar to the 16S rRNA sequence of $R$. marinus but less than $80 \%$ similar to any other sequences. This result suggested that the new isolate belongs to the genus Rhodothermus. Therefore,

TABLE 1. Maximum cell yields and growth rates for $R$. obamensis $O K D 7^{\mathrm{T}}$ with various carbon-containing substrates ${ }^{a}$

\begin{tabular}{|c|c|c|}
\hline Substrate(s) & $\begin{array}{l}\text { Specific } \\
\text { growth rate } \\
(\%)^{b}\end{array}$ & $\begin{array}{l}\text { Maximum } \\
\text { cell density } \\
\text { (cells/ml) }\end{array}$ \\
\hline Yeast extract $(0.1 \%)+$ peptone $(0.1 \%)$ & 100 & $2 \times 10^{9}$ \\
\hline Yeast extract $(0.1 \%)$ & 89 & $1 \times 10^{9}$ \\
\hline Peptone $(0.1 \%)$ & 96 & $1 \times 10^{9}$ \\
\hline Glucose $(0.01 \%)$ & 64 & $1 \times 10^{8}$ \\
\hline Glucose $(0.05 \%)$ & 22 & $7 \times 10^{7}$ \\
\hline Glucose $(0.1 \%)$ & 7 & $4 \times 10^{7}$ \\
\hline Galactose $(0.01 \%)$ & 66 & $2 \times 10^{8}$ \\
\hline Maltose $(0.01 \%)$ & 45 & $1 \times 10^{8}$ \\
\hline Sucrose $(0.01 \%)$ & 86 & $5 \times 10^{8}$ \\
\hline Cellobiose $(0.01 \%)$ & 70 & $2 \times 10^{8}$ \\
\hline Mannitol $(0.01 \%)$ & 77 & $4 \times 10^{8}$ \\
\hline Sorbitol $(0.01 \%)$ & 80 & $2 \times 10^{8}$ \\
\hline Xylose $(0.01 \%)$ & 0 & \\
\hline Starch $(0.01 \%)$ & 80 & $5 \times 10^{8}$ \\
\hline Lactate $(0.1 \%)$ & 28 & $8 \times 10^{7}$ \\
\hline Pyruvate $(0.01 \%)$ & 5 & $4 \times 10^{7}$ \\
\hline Pyruvate $(0.05 \%)$ & 44 & $8 \times 10^{7}$ \\
\hline Pyruvate $(0.1 \%)$ & 72 & $2 \times 10^{8}$ \\
\hline Glycerol $(0.01 \%)$ & 0 & \\
\hline Glycerol $(0.1 \%)$ & 0 & \\
\hline Casein $(0.1 \%)$ & 65 & $2 \times 10^{8}$ \\
\hline Casamino Acids ( $0.1 \%)$ & 95 & $7 \times 10^{8}$ \\
\hline Glycine $(0.1 \%)$ & 44 & $9 \times 10^{7}$ \\
\hline Alanine $(0.1 \%)$ & 52 & $1 \times 10^{8}$ \\
\hline Leucine $(0.01 \%)$ & 0 & \\
\hline Leucine $(0.1 \%)$ & 0 & \\
\hline Serine $(0.1 \%)$ & 33 & $8 \times 10^{7}$ \\
\hline Threonine $(0.1 \%)$ & 35 & $9 \times 10^{7}$ \\
\hline Valine $(0.01 \%)$ & 27 & $6 \times 10^{7}$ \\
\hline Valine $(0.1 \%)$ & 0 & \\
\hline Proline $(0.1 \%)$ & 25 & $9 \times 10^{7}$ \\
\hline Arginine $(0.1 \%)$ & 44 & $8 \times 10^{7}$ \\
\hline Aspartate $(0.1 \%)$ & 48 & $1 \times 10^{8}$ \\
\hline Glutamine $(0.01 \%)$ & 0 & \\
\hline Glutamine $(0.1 \%)$ & 0 & \\
\hline
\end{tabular}

${ }^{a}$ All preparations were incubated at $75^{\circ} \mathrm{C}$ with shaking at $100 \mathrm{rpm}$, and the initial $\mathrm{pH}$ of each medium was adjusted to 6.8 to 7.2 with $\mathrm{H}_{2} \mathrm{SO}_{4}$ or $\mathrm{NaOH}$.

${ }^{b}$ The specific growth rate in the medium containing $0.1 \%$ yeast extract and $0.1 \%$ peptone was defined as $100 \%$. 
TABLE 2. Comparison of some characteristics of $R$. obamensis, $R$. marinus, and the genera Thermus and Thermomicrobium

\begin{tabular}{|c|c|c|c|c|}
\hline Characteristic & R. obamensis & R. marinus ${ }^{a}$ & Thermus $^{b}$ & Thermomicrobium $^{c}$ \\
\hline Cell length $(\mu \mathrm{m})$ & $4-10$ & $2-2.5$ & $5-10$ & $3-6$ \\
\hline Colony color(s) & Reddish & Reddish & $\begin{array}{l}\text { Yellow, orange, red, } \\
\text { transparent }\end{array}$ & Red \\
\hline Optimum temp $\left({ }^{\circ} \mathrm{C}\right)$ & 80 & 65 & $70-75$ & $70-75$ \\
\hline Generation time (min) & 90 & 80 & $20-60$ & 330 \\
\hline \multicolumn{5}{|l|}{ Growth in the presence of: } \\
\hline $0 \% \mathrm{NaCl}$ & - & - & + & + \\
\hline $3 \% \mathrm{NaCl}$ & + & + & - & - \\
\hline $6 \% \mathrm{NaCl}$ & - & + & - & - \\
\hline \multicolumn{5}{|l|}{ Growth on: } \\
\hline Xylose & - & + & - & $\mathrm{NR}^{d}$ \\
\hline Sorbitol & + & - & - & NR \\
\hline Casein & + & - & + & + \\
\hline Casamino Acids & + & - & - & NR \\
\hline Glutamine & - & + & Variable & NR \\
\hline Proline & + & - & + & NR \\
\hline Serine & + & - & Variable & NR \\
\hline Oxidase & + & + & + & NR \\
\hline Catalase & + & + & + & NR \\
\hline $\mathrm{G}+\mathrm{C}$ content $(\mathrm{mol} \%)$ & 66.6 & 65 & $57-65$ & NR \\
\hline Major fatty acid(s) & $\begin{array}{l}\text { iso- } \mathrm{C}_{15} \text {, iso- } \mathrm{C}_{17} \text {, anteiso- } \mathrm{C}_{15} \text {, } \\
\quad \text { anteiso- } \mathrm{C}_{17}\end{array}$ & NR & iso- $\mathrm{C}_{15}$, iso- $\mathrm{C}_{17}$ & $\begin{array}{l}\text { Internally branched } \\
12 \text {-methyl- } \mathrm{C}_{18}\end{array}$ \\
\hline Major isoprenolog(s) & MK-7, MK-6, MK-5 & NR & MK-8 & NR \\
\hline
\end{tabular}

${ }^{a}$ Data from references 2 and 20.

${ }^{b}$ Data from references 4,5 , and 20 .

'Data from references 2 and 13.

${ }^{d} \mathrm{NR}$, not reported.

in order to determine the phylogenetic position of the genus Rhodothermus, including $\mathrm{OKD} 7^{\mathrm{T}}$, evolutionary distances based on the $16 \mathrm{~S}$ rRNA gene sequences of several members of the Bacteria and Archaea were calculated and a phylogenetic tree was reconstructed by using the neighbor-joining method (Fig. 3).

On the phylogenetic tree, new isolate $\mathrm{OKD} 7^{\mathrm{T}}$ was located

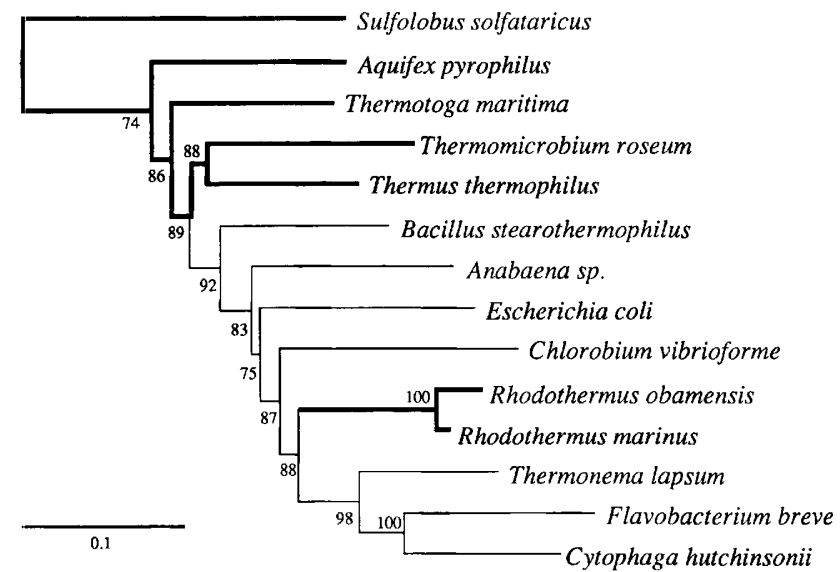

FIG. 3. Phylogenetic tree showing the positions of representative members of the Bacteria and Archaea inferred from 16S rRNA sequence data. The thick lines indicate hyperthermophilic or extremely thermophilic branches and possible thermophilic origins of life. The numbers are the bootstrap values for the branches (based on 100 replicates). Scale bar $=0.1$ substitution per nucleotide. The GenBank nucleotide sequence accession numbers for the organisms used in the analysis are as follows: Sulfolobus solfataricus, X03235; Aquifex pyrophilus, M83548; Thermotoga maritima, M21774; Thermomicrobium roseum, M34115; Thermus thermophilus, X07998; Bacillus stearothermophilus, X57309; Anabaena sp., X59559; Escherichia coli, V00348; Chlorobium vibrioforme, M62791; Rhodothermus obamensis, X95071; Rhodothermus marinus, X80994; Thermonema lapsum, L11703; Flavobacterium breve, M59052; and Cytophaga hutchinsonii, M58768. along with $R$. marinus close to the root of the FlexibacterCytophaga-Bacteroides group and did not represent a deep branch within the domain Bacteria, which was consistent with the phylogenetic position of $R$. marinus determined previously (3). The bootstrap confidence data supported the robustness and significance of the placement of $\mathrm{OKD}^{\mathrm{T}}$ and $R \cdot m a$ rinus.

\section{DISCUSSION}

The new isolate was a gram-negative, rod-shaped, aerobic extreme thermophile and appeared to be a member of the domain Bacteria because of its morphological and physiological similarities to other thermophilic bacteria. Representatives of thermophilic genera belonging to this domain have been isolated from various hydrothermal vents and terrestrial hot springs $(2,5,10,11,13,17,20)$. On the basis of physiological properties, the new isolate resembled members of three extremely thermophilic genera, the genera Thermus, Thermomicrobium, and Rhodothermus (Table 2). However, the new isolate was significantly different from members of the genera Thermus and Thermomicrobium as determined by chemotaxononic characteristics. Although the major fatty acid components of the new isolate were similar to those of Thermus strains the new isolate contained menaquinone 7 as its major isoprenolog; this menaquinone not only is different from the major menaquinone of Thermus strains (Table 2) but also is rare among the gram-negative bacteria (8). When the major cellular fatty acids were compared, Thermomicrobium strains had high levels of internally branched fatty acids, primarily 12-methyl $C_{18}$ fatty acid $(4,13)$, which were quite different in their branching patterns and chain lengths from the predominant fatty acids of the new isolate (Table 2).

The finding that the $16 \mathrm{~S}$ rRNA sequence of the new isolate exhibited $95 \%$ homology with the sequence of $R$. marinus suggests that the new isolate belongs to the genus Rhodothermus. 
The members of the genus Rhodothermus are aerobic, heterotrophic thermophiles that have been isolated recently from sites in Iceland and the Azores $(2,20)$. R. marinus is a marine thermophile which grows at temperatures between 54 and $77^{\circ} \mathrm{C}$ (optimum temperature, $65^{\circ} \mathrm{C}$ ) and utilizes a variety of sugars and carboxylic acids as sole carbon and energy sources $(2,20)$. In contrast, the new isolate is an extreme thermophile that grows at temperatures up to $85^{\circ} \mathrm{C}$, has an optimum temperature of $80^{\circ} \mathrm{C}$ (Fig. 2), and utilizes different carbon-containing substrates for growth (Table 2). Unlike $R$. marinus, the new isolate utilizes sorbitol, casein, Casamino Acids, proline, and serine and does not utilize xylose or glutamine as a sole carbon and energy source (Table 2). Moreover, the morphology and salt tolerance of $\mathrm{OKD} 7^{\mathrm{T}}$ and $R$. marinus are different and the evolutionary distance between these taxa based on 16S rRNA sequence data is equivalent to the distances used to distinguish species within the domain Bacteria. On the basis of the results described above, we propose that the new isolate is a member of a new species of the genus Rhodothermus, Rhodothermus obamensis. The type strain of $R$. obamensis is strain OKD7.

On the basis of its optimal growth in the presence of $3 \%$ $\mathrm{NaCl}, R$. obamensis is a typical marine organism similar to $R$. marinus. It was thought previously that members of the genus Thermus are the most common heterotrophs in submarine hot springs, as well as in terrestrial hot springs $(15,16)$. However, members of at least two heterotrophic genera in the Bacteria, the genera Thermotoga and Rhodothermus, have been isolated from submarine hydrothermal environments $(2,10,20)$, and it has also been suggested that there are uncultivable heterotrophic thermophiles (22). The isolation of a member of the genus Rhodothermus from Japan submarine hydrothermal vents leads to the speculation that this genus may be widely distributed in submarine hydrothermal environments.

The results of the phylogenetic analysis of the $16 \mathrm{~S}$ rRNA sequence demonstrated the significance of the phylogeny of the genus Rhodothermus on the bacterial phylogenetic tree (Fig. 3). Interestingly, both of the Rhodothermus species are most closely related to the members of Flexibacter-CytophagaBacteroides group. The results of recent phylogenetic studies of thermophilic members of the Bacteria and Archaea have suggested that the deep branches on the universal tree are occupied by thermophiles and have implied that the common ancestor of all present-day organisms might be a thermophile $(1$, $7,11,26,29,30)$. Nevertheless, there has been some evidence against this hypothesis that has been based on the phylogeny of other proteins $(23,25)$ and the evolution of the reverse gyrase gene (9). In addition, the members of a group of thermophiles (the genera Rhodothermus and Thermonema) placed close to the root of the Flexibacter-Cytophaga-Bacteroides group are not deep branches ( 3 ; this study), and there are diverse thermophilic members of the Bacteria that are only distantly related to the universal root (4). The discovery of the extreme thermophile $R$. obamensis, whose lineage is apparently modern, suggests that extreme thermophily is not necessarily an ancient characteristic but may have a second, modern origin within the Bacteria.

Description of Rhodothermus obamensis Sako, Takai, Ishida, Uchida, and Katayama sp. nov. Rhodothermus obamensis (o.bam'en.sis. L. gen. n. obamensis, of Obama, a hot spring in Japan). Cells are gram-negative, straight rods that are about 4 to $10 \mu \mathrm{m}$ long and 0.5 to $1.0 \mu \mathrm{m}$ wide and occur singly and in aggregates; they are extremely long during the stationary growth phase. Colonies are reddish and 1 to $2 \mathrm{~mm}$ in diameter with entire edges. Aerobic, thermophilic, neutrophilic heterotroph. Growth occurs at temperatures between 50 and $85^{\circ} \mathrm{C}$ (optimum temperature, $80^{\circ} \mathrm{C}$ ), at $\mathrm{pH} 5.5$ and 9.0 (optimum $\mathrm{pH}$,
7.0), and in the presence of 1 to $5 \% \mathrm{NaCl}$ (optimum $\mathrm{NaCl}$ concentration, $3 \%$ ). Oxidase and catalase positive. The major cellular fatty acid components are anteiso- and iso- $\mathrm{C}_{17}$ and anteiso- and iso- $\mathrm{C}_{15}$ acids. The major quinone is menaquinone 7; smaller amounts of menaquinones 6 and 5 are also present. Growth occurs on complex medium containing yeast extract and peptone and on medium containing glucose, galactose, sucrose, maltose, cellobiose, sorbitol, mannitol, starch, lactate, pyruvate, casein, Casamino Acids, arginine, aspartate, glycine, alanine, serine, threonine, or proline. The DNA base composition is $66.6 \mathrm{~mol} \%$. The $16 \mathrm{~S}$ rRNA of $R$. obamensis is $95 \%$ similar to $R$. marinus $16 \mathrm{~S}$ rRNA.

The type strain is $R$. obamensis OKD7 (= JCM 9785), which was isolated from a site in Tachibana Bay, Nagasaki, Japan.

\section{ACKNOWLEDGMENTS}

This work was supported in part by Grant-in-Aid for Scientific Research 07556048 from the Ministry of Education, Science and Culture of Japan.

We thank John A. Baross and James F. Holden, University of Washington, for advice and also thank Paul Smith, University of West Sydney, Sydney, Australia, for correcting the English.

\section{REFERENCES}

1. Achenbach-Richter, L., R. Gupta, K. O. Stetter, and C. R. Woese. 1987 Were the original eubacteria thermophiles? Syst. Appl. Microbiol. 9:34-39.

2. Alfredsson, G. A., J. K. Kristjansson, S. Hjörleifsdottir, and K. O. Stetter. 1988. Rhodothermus marinus, gen. nov., sp. nov., a thermophilic, halophilic bacterium from submarine hot springs in Iceland. J. Gen. Microbiol. 134: 49-68.

3. Andrésson, ó. S., and Ó. H. Friōjónsson. 1994. The sequence of the single $16 \mathrm{~S}$ rRNA gene of the thermophilic eubacterium Rhodothermus marinus reveals a distant relationship to the group containing Flexibacter, Bacteroides, and Cytophaga species. J. Bacteriol. 176:6165-6169.

4. Brock, T. D. 1986. Introduction: an overview of the thermophiles, p. 1-16. In T. D. Brock (ed.), Thermophiles. Wiley-Interscience, New York.

5. Brock, T. D., and M. L. Brock. 1984. Genus Thermus Brock and Freeze 1969, $295^{\mathrm{AL}}$, p. 333-337. In N. R. Krieg and J. G. Holt (ed.), Bergey's manual of systematic bacteriology, vol. 1. Williams and Wilkins, Baltimore.

6. Brosius, J., J. L. Palmer, J. P. Kennedy, and H. F. Noller. 1978. Complete nucleotide sequence of a 16S ribosomal RNA gene from Escherichia coli. Proc. Natl. Acad. Sci. USA 75:4801-4805.

7. Burggraf, S., G. J. Olsen, K. O. Stetter, and C. R. Woese. 1992. A phylogenetic analysis of Aquifex pyrophilus. Syst. Appl. Microbiol. 15:352-356.

8. Collins, M. D., and D. Jones. 1981. Distribution of isoprenoid quinone structural types in bacteria and their taxonomic implications. Microbiol. Rev. 45:316-354.

9. Forterre, P., F. Confalonieri, F. Charbonnier, and M. Dugnet. 1995. Speculations on the origin of life and thermophily: review of available information on reverse gyrase suggests that hyperthermophilic prokaryotes are not so primitive. Origin Life Evol. Biosphere 25:235-249.

10. Huber, R., T. A. Langworthy, H. König, M. Thomm, C. R. Woese, U. B. Sleytr, and K. O. Stetter. 1986. Thermotoga maritima sp. nov. represents a new genus of unique extremely thermophilic eubacteria growing up to $90^{\circ} \mathrm{C}$. Arch. Microbiol. 144:324-333.

11. Huber, R., T. Wilharm, D. Huber, A. Trincone, S. Burggraf, H. König, R. Rachel, I. Rockinger, H. Fricke, and K. O. Stetter. 1992. Aquifex pyrophilus gen. nov. sp. nov, represents a novel group of marine hyperthermophilic hydrogen-oxidizing bacteria. Syst. Appl. Microbiol. 15:340-351.

12. Ishii, M., T. Kawasumi, Y. Igarashi, T. Kodama, and Y. Minoda. 1987. 2-Methylthio-1,4-naphthoquinone, a unique sulfur-containing quinone from a thermophilic hydrogen-oxidizing bacterium, Hydrogenobacter thermophilus. J. Bacteriol. 169:2380-2384

13. Jackson, T. J., R. F. Ramaley, and W. G. Meinschein. 1973. Thermomicrobium, a new genus of extremely thermophilic bacteria. Int. J. Syst. Bacteriol. 23:28-36.

14. Kawasumi, T., Y. Igarashi, T. Kodama, and Y. Minoda. 1984. Hydrogenobacter thermophilus gen. nov., sp. nov., an extremely thermophilic, aerobic, hydrogen-oxidizing bacterium. Int. J. Syst. Bacteriol. 34:5-10.

15. Kristjansson, J. K., and G. A. Alfredsson. 1986. Life in Icelandic hot springs. Natturufraedingurinn 56:49-68.

16. Kristjansson, J. K., G. O. Hregridsson, and G. A. Fredsson. 1986. Isolation of halotolerant Thermus spp. from submarine hot springs in Iceland. Appl. Environ. Microbiol. 52:1313-1316.

17. Kristjansson, J. K., A. Ingason, and G. A. Alfredsson. 1985. Isolation of thermophilic obligately autotrophic hydrogen-oxidizing bacteria, similar to 
Hydrogenobacter thermophilus from Icelandic hot springs. Arch. Microbiol. 140:321-325

18. Lauerer, G., J. K. Kristjansson, T. A. Langworthy, H. König, and K. O. Stetter. 1986. Methanothermus sociabilis sp. nov., a second species within the Methanothermaceae growing at $97^{\circ} \mathrm{C}$. Syst. Appl. Microbiol. 8:100-105.

19. Marmur, J., and P. Doty. 1962. Determination of the base composition of deoxyribonucleic acid from its thermal denaturation temperature. J. Mol. Biol. 5:109-118.

20. Nunes, O. C. M. M. Donato, and M. S. Da Costa. 1992. Isolation and characterization of Rhodothermus strains from S. Miguel, Azores. Syst. Appl. Microbiol. 15:92-97.

21. Olsen, G. J., C. R. Woese, and R. Overbeek. 1994. The winds of (evolutionary) change: breathing new life into microbiology. J. Bacteriol. 176:1-6.

22. Reysenbach, A.-L., G. S. Wickham, and N. R. Pace. 1994. Phylogenetic analysis of the hyperthermophilic pink filament community in Octopus Spring, Yellowstone National Park. Appl. Environ. Microbiol. 60:2113-2119.

23. Rivera, M. C., and J. A. Lake. 1992. Evidence that eukaryotes and eocyte prokaryotes are immediate relatives. Science 257:74-76.

24. Saitou, N., and M. Nei. 1987. The neighbor-joining method: a new method for reconstructing phylogenetic trees. Mol. Biol. Evol. 4:406-425.

25. Sanangelantoni, A. M., M. Bocchetta, P. Cammarano, and O. Tiboni. 1994.
Phylogenetic depth of S10 and spc operons: cloning and sequencing of a ribosomal protein gene cluster from the extremely thermophilic bacterium Thermotoga maritima. J. Bacteriol. 176:7703-7710.

26. Shima, S., M. Yanagi, and H. Saiki. 1994. The phylogenetic position of Hydrogenobacter acidophilus based on 16S rRNA sequence analysis. FEMS Microbiol. Lett. 119:119-122.

27. Tamaoka, J., and K. Komagata. 1984. Determination of DNA base composition by reversed-phase high-performance liquid chromatography. FEMS Microbiol. Lett. 25:125-128.

28. Thorbjarnardóttir, S. H., Z. O. Jónsson, Ó. S. Andrésson, J. K. Kristjánsson, G. Eggertsson, and A. Palsdottir. 1995. Cloning and sequence analysis of the DNA ligase-encoding gene of Rhodothermus marinus, and overproduction, purification and characterization of two thermophilic DNA ligases. Gene 161:1-6.

29. VölkI, P., R. Huber, E. Drobner, R. Rachel, S. Burggraf, A. Trincone, and K. O. Stetter. 1993. Pyrobaculum aerophilus $\mathrm{sp}$. nov., a novel nitrate-reducing hyperthermophilic archaeum. Appl. Environ. Microbiol. 59:2918-2926.

30. Woese, C. R. 1987. Bacterial evolution. Microbiol. Rev. 51:221-271.

31. Woese, C. R., O. Kandler, and M. L. Wheels. 1990 . Towards a natural system of organisms: proposal for the domains Archaea, Bacteria, and Eucarya. Proc. Natl. Acad. Sci. USA 87:4576-4579. 